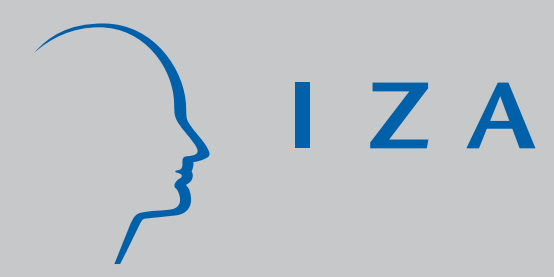

IZA DP No. 2519

Reconciling the Estimates of Potential Migration into the Enlarged European Union

Anzelika Zaiceva

December 2006 


\title{
Reconciling the Estimates of Potential Migration into the Enlarged European Union
}

\author{
Anzelika Zaiceva
}

IZA Bonn

\author{
Discussion Paper No. 2519 \\ December 2006
}

\author{
IZA \\ P.O. Box 7240 \\ 53072 Bonn \\ Germany \\ Phone: +49-228-3894-0 \\ Fax: +49-228-3894-180 \\ E-mail: iza@iza.org
}

\begin{abstract}
Any opinions expressed here are those of the author(s) and not those of the institute. Research disseminated by IZA may include views on policy, but the institute itself takes no institutional policy positions.

The Institute for the Study of Labor (IZA) in Bonn is a local and virtual international research center and a place of communication between science, politics and business. IZA is an independent nonprofit company supported by Deutsche Post World Net. The center is associated with the University of Bonn and offers a stimulating research environment through its research networks, research support, and visitors and doctoral programs. IZA engages in (i) original and internationally competitive research in all fields of labor economics, (ii) development of policy concepts, and (iii) dissemination of research results and concepts to the interested public.
\end{abstract}

IZA Discussion Papers often represent preliminary work and are circulated to encourage discussion. Citation of such a paper should account for its provisional character. A revised version may be available directly from the author. 
IZA Discussion Paper No. 2519

December 2006

\section{ABSTRACT \\ Reconciling the Estimates of Potential Migration into the Enlarged European Union}

This paper briefly reviews the existing literature on potential migration into the enlarged European Union, reconciles the results with recent evidence and presents an additional migration scenario. The estimation procedure accounts for both sending and receiving countries' unobserved heterogeneity, and in the simulations a counterfactual scenario is calculated, in which all EU member states introduce free movement of workers simultaneously in 2011. The results suggest that the overall level of migration from the East will amount to around 1 per cent of the EU15 population within a decade after enlargement, and that the legal introduction of free movement of workers will not increase immigration significantly. These findings are compared both with the previous literature and emerging evidence.

JEL Classification: F22, J11, J61

Keywords: migration extrapolations, EU enlargement, panel data

Corresponding author:

Anzelika Zaiceva

IZA

P.O. Box 7240

D-53072 Bonn

Germany

E-mail: zaiceva@iza.org

\footnotetext{
* I would like to thank Andrea Ichino for guidance, support and helpful advice, Thomas Bauer for sharing the data and Klaus F. Zimmermann for helpful comments. I am grateful to Fabian Bornhorst, Olmo Silva, Charles Grant, Michael Artis and seminar participants at IZA, European University Institute, CESifo and IX Spring Meeting of Young Economists for their comments. All remaining errors are mine. This is a substantially revised version of CESlfo Working Paper No. 1184 entitled "Implications of EU Accession for International Migration: An Assessment of Potential Migration Pressure".
} 


\section{Introduction}

Two years after the enlargement of the European Union $(\mathrm{EU})^{1}$ labor migration from the East remains one of the most widely debated topics both in academia and in policy making. The last enlargement was unprecedented: income differentials were large, there existed no previous free migration record, Central and Eastern European countries (CEECs) have undergone a transition from socialist to market economies, and they represented quite heterogeneous countries. Since large wage and income differentials between these regions are likely to remain for decades, strong economic incentives to migrate will also persist. However, it is also well known that international migration is hindered by high transaction costs, limited absorptive capacities of the receiving countries' labor markets, and by cultural and linguistic heterogeneity within Europe.

Long before the accession, emigration from the new member states attracted a significant public attention. On the one hand, the adoption of the common currency within the enlarged EMU means that labor mobility would provide a means to dampen negative impacts of idiosyncratic shocks. On the other hand, there were political concerns about the potential for huge flows of immigrants from CEECs, which could undermine the western welfare state. Due to intensive political pressure, a transition period of up to seven years for the free movement of labor was accepted, with only Ireland, the UK and Sweden opening their labor markets immediately to CEEC nationals. Note that the introduction of such transition periods represents a classical example of coordination fail-

\footnotetext{
${ }^{1}$ In May 2004 Cyprus, Czech Republic, Estonia, Hungary, Latvia, Lithuania, Malta, Poland, Slovakia and Slovenia joined the EU.
} 
ure: given that the most affected countries will use transitional periods to protect their labor markets, other countries which planned to open their labor markets immediately come under increasing pressure, since migration flows will be diverted away from the large immigration countries to those that have already opened their labor markets (Boeri and Brücker, 2005).

These transitional arrangements were up for review in 2006 after the actual migration patterns from the new member states had been evaluated. Following this review in early 2006, four member states (Greece, Spain, Portugal, and Finland) decided to lift restrictions for the second, three-year phase of the arrangements starting on 1 May 2006, while six other countries (Belgium, Denmark, France, Italy, the Netherlands, and Luxembourg) decided to alleviate them. In late July 2006, the Italian government also decided to terminate the transitional arrangement and to give workers from the new member states full access to the Italian labor market. ${ }^{2}$

Experience with previous European integration suggests that migration flows do not increase dramatically after opening up the borders. Similar transition periods were introduced after the accession of southern countries: Greece in 1981, and Portugal and Spain in 1986. In spite of income differentials, however, the flows of immigrants from these new members were small (Eurostat, 2000). As for the recent EU enlargement, there exists a relatively large empirical literature that, in general, seems to reach the same conclusions. This paper briefly reviews existing empirical studies and compares the results, following which my own migration scenario is presented. The main contribution to the existing

\footnotetext{
${ }^{2}$ See European Commission (2006) and EURES portal.
} 
literature is that it first accounts only for receiving countries' and then for both receiving and sending countries' unobserved heterogeneity and estimates a counterfactual situation, assuming that all EU incumbents would introduce free movement of labor for all new member states simultaneously in 2011. This scenario answers the questions about what would have happened if, following political pressures, all EU15 members had imposed restrictions on immigration from the new member states until 2011. The results from the existing literature are then contrasted with the actual evidence that became available only recently.

The findings of the existing studies are heterogeneous; however, in spite of using different model specifications and methodologies, the vast majority finds that between 2 and 4 per cent of the CEECs' population will move West in the long run, which constitutes around 1 per cent of the EU15 population. The results from the scenario presented here are consistent with the majority of the existing studies. They also suggest that the overall level of (legal and permanent) migration from the East within a decade after enlargement will amount to around 1 per cent of the EU15 population. In addition, it is found that the legal introduction of free movement of workers in 2011 would not increase immigration significantly.

Regarding the actual evidence, on aggregate it appears that the magnitude of migration flows after enlargement is in line with the majority of models. However, due to the problem of migration diversion, actual migration flows to some individual countries, such as Ireland and the UK, are much higher than was predicted.

The rest of the paper is structured as follows. Section 2 reviews the existing theoretical 
framework and empirical studies on potential migration after EU enlargement. Estimation results and extrapolations, as well as comparisons with other studies, are presented in section 3. Section 4 presents the recent actual evidence. Section 5 concludes.

\section{Literature Review}

\subsection{Theoretical Framework}

In neoclassical migration theory, migration decisions are based on considerations of the relative expected future incomes, adjusted for the costs of migrating (Todaro, 1969, Harris and Todaro, 1970). An individual migrates if the expected income (expected utility) in the host country is greater than that of the country of origin. Sjaastad (1962) views migration as an investment in human capital and emphasizes heterogeneity among individuals. This model argues that, depending on their skills, individuals calculate the present discounted value of the expected returns to their human capital, and migration occurs if the returns, net of the discounted costs of moving (both material and psychological, as well as foregone earnings), are larger in the destination country than in the country of origin.

Stark (1984) views migration as a household decision and emphasizes the risk diversification motive. Ghatak et al. (1996) argue that individual liquidity constraints should be taken into account. People who wish to migrate usually face liquidity / borrowing constraints, and a marginal rise in their home country's income might simply ease such constraints and raise the rate of migration. The network approach (Massey, 1993) incor- 
porates migrant networks - sets of interpersonal, cultural or linguistic ties that connect migrants and non-migrants in the origin and destination countries. According to this framework, migration may become a self-perpetuating process because the costs and risks of migration decrease as the stock of migrants already living in the host country grows, leading to higher net returns to mobility. Another strand of theoretical literature uses an option value theory of migration (Burda, 1995). This model incorporates uncertainty and irreversibility of the migration decision. It postulates that if the migration decision is postponable and if income convergence is expected, it is better for a potential migrant to "wait and see". Finally, Hatton (1995) derives an estimable model of the migration rate. The model incorporates uncertainty and postulates that migration decisions are based upon expectations of future economic developments. It assumes that the individual migration decision is determined by considerations of relative earnings, employment, and non-pecuniary costs of migration.

Due to severe data limitations, empirical work usually cannot take into account all of the socio-economic push and pull factors that affect migration, such as traditions and networks, ethnic and political problems, cultural and linguistic barriers as well as geographic proximity. The next subsection reviews the existing empirical studies on potential migration after enlargement.

\section{$2.2 \quad$ Empirical Literature}

There exists a substantial empirical literature that attempts to predict future migration flows from the new EU member states. It is difficult to compare the results of these 
studies, since they vary in the methodology used and in the range of variables included into the model. Nevertheless, in spite of the large heterogeneity, the majority finds that between 2 and 4 per cent of the CEECs' population will move West in the long run, which would constitute about 1 per cent of the EU15 population. Since essentially no migration from the accession countries into Western Europe took place after World War II, no data is available for these countries. Therefore, typically the first step is to estimate the association between past migration flows from countries other than CEECs and explanatory variables, such as differences in income levels and unemployment rates, past migration flows and different institutional variables. Then, in the second step, future migration flows are predicted for the CEECs based on the estimated results. ${ }^{3}$ In order to provide an overview of the findings, only selected contributions are reviewed here. ${ }^{4}$

In the pioneer study, Layard et al. (1992) use migration flows from Southern Europe to other European countries and North America in the 1950s and 1960s as well as migration flows from Mexico into the United States in the 1970s and 1980s, in order to calculate the potential of East-West migration in Europe. They conclude that at least 3 per cent of the CEECs' citizens will move westwards after the enlargement. Lundborg (1998) follows the same approach and extrapolates the potential migration from Poland and the Baltic states to the EU15 to reach at most 0.5 per cent of the EU population within fifteen years.

Franzmeyer and Brücker (1997) use extrapolations based on a cross-sectional model

\footnotetext{
${ }^{3}$ Another strand of literature analyzes emigration intentions from new member states using surveys (see, for example, Fassmann and Hintermann, 1997, Wallace, 1998). This literature is not reviewed here since I focus on econometric models.

${ }^{4}$ For earlier surveys see, for example, Alvarez-Plata et al. (2003) and Boeri et al. (2001).
} 
and estimate the annual net inflow from five accessions countries (Czech Republic, Hungary, Poland, Slovakia and Slovenia) into the EU15 to range between 0.5 and 1 per cent of sending countries' population.

Bauer and Zimmermann (1999), basing their analysis on Southern EU enlargement, estimate regressions with sending country-specific effects under two scenarios, one for restricted mobility and another for free mobility. They find that in the baseline ("total") scenario the largest emigration rates are expected for Romania (6.5 per cent), Bulgaria (3.2 per cent) and Poland (1.8 per cent), and the lowest rate for Slovenia (0.2 per cent). Another strand of the empirical literature estimates a so-called "gravity model" for a cross-section of countries, regressing migrant stocks or net migration rates on standard macroeconomic variables as well as on the distance between the countries. Orlowski et al. (2000) exploit this approach to estimate potential migration from ten CEECs into Austria. The authors find that the majority of CEEC migrants will come from Romania and Poland, and the total migration potential to Austria is about 2.3-3.7 per cent of the Austrian population. Hille and Straubhaar (2001) also exploit Southern EU enlargement and estimate a gravity model for the period of unrestricted mobility. They suggest annual migration flows into the EU to be equal to 0.3 per cent of the CEEC population (0.1 per cent of the EU15 population).

Sinn et al. (2000) and Flaig (2001), using data on migration from Greece, Italy, Portugal, Spain and Turkey to Germany over 1974-1997, estimate a dynamic model and simulate migration potential from Poland, Czech Republic, Slovakia, Hungary and Romania under a free mobility assumption. They find that the steady-state migrant stock in Germany 
will be equal to 3.2-4 million people in fifteen years, depending on income convergence scenario, which would constitute around 4-5 per cent of the German population.

However, as Brücker (2001) points out, the hypothesis that a common constant applies to all countries is rejected by all statistical tests, which means that results from the models that do not account for country-specific effects are seriously biased. In addition, Alecke et al. (2001) show that models that do not account for country-specific effects, such as standard gravity models, consistently overestimate migration, and that one should include these fixed effects to account for many push and pull factors suggested by modern migration theory. However, since within-sample countries do not overlap with future accession countries, it is unclear which country-specific terms to use for predictions. Straubhaar (2001) notes that it remains "more than crucial" how the country-specific effects are defined and applied to the CEECs, which have no historical experience of free migration.

Fertig and Schmidt (2001) argue that a convincing choice of the country-specific intercepts for countries for which no previous migration record exists is the principal conceptual challenge for the prediction - yet, this identification problem has not been addressed formally in any of the previous papers on this topic. The authors therefore estimate an error-components model which assumes that migration is explained solely by an overall intercept, a random country-specific component and a time-series component. Estimating net migration rates from 17 different countries into Germany, the authors forecast the cumulative migration from four CEE countries (Poland, Czech Republic, Hungary, and Estonia) to Germany to reach 300,000-1,200,000 people (0.4-1.5 per cent of Germany's 
population) within twenty years. Dustmann et al. (2003) also use data on migration from 17 different countries into Germany and the UK and estimate a variance-components model for net migration flows. They find that, depending on the model specification and income convergence scenario, potential annual net immigration flows from ten accession countries into Germany range between 20,000 and 200,000 people and to the UK from 5,000 to 13,000. However, this approach does not consider any economic and/or institutional variables, such as the introduction of free movement.

Fertig (2001) and Boeri et al. (2001) use a different approach. To at least reduce the problem of country-specific effects for out-of-sample countries, in the first stage, a dynamic model of migration is estimated for Germany, including sending countries' fixed effects. In the second stage, these effects are regressed on time-invariant distance and country development indicators in order to include them into extrapolations for the CEECs. Fertig's (2001) estimates yield the stock of CEECs citizens in Germany in 2015 to range from 1.6 to 2 percent of Germany's population (1.3-1.4 per cent of the CEEC population), depending on the GDP convergence scenario and the assumptions regarding free movement. Boeri et al. (2001) also use this approach and estimate that between 1.9 and 3 per cent of the CEEC population will reside in Germany in 2030 (2.3-3.6 per cent of the German population), and the extrapolations for the EU15 equal to around 4 per cent of the CEEC population and to 1 per cent of the EU15 population, respectively. The largest emigration flow is expected from Romania, Bulgaria, and Poland, and the most affected countries are expected to be Germany and Austria. The follow-up update of Alvarez-Plata et al. (2003) estimates a slightly lower migration potential and presents 
several scenarios regarding introduction of free movement. ${ }^{5}$ Note, however, that in these studies, the pool of 17 sending countries is very heterogeneous and varies from the US and Switzerland to ex-Yugoslavia.

All of this literature is subject to many problems and criticism. The main methodological problems include the so-called double out-of-sample extrapolations (for ten countries that have not been included in the estimated sample and for the years outside the estimation period) and associated forecast errors, equality of slope coefficients (assumption that estimated parameters will have the same relevance for the new member states), as well as strong assumptions about the future development of explanatory variables. In addition, empirical specifications remain rather ad hoc. Moreover, it is not always clear how the introduction of a free movement provision is dealt with in these studies. ${ }^{6}$ In addition, estimating such double out-of-sample projections, the existing studies inevitably face, among others, a problem of forecasting performance. Nevertheless, Alvarez-Plata et al. (2003) and Brücker and Siliverstovs (2006) test different estimation procedures used in these studies on their out-of-sample performance and conclude that SUR and fixed effects estimators outperform others in dynamic simulations.

In the remainder of the paper I present my own simulation of potential migration that first accounts only for receiving and then for both sending and receiving country-

\footnotetext{
${ }^{5}$ Note also that in Alvarez-Plata et al. (2003) the counterfactual scenarios of different dates when the free movement of workers is introduced were estimated (a complete freedom of movement vs. a complete restriction). They conclude that transitional periods may divert migration flows away from countries that restrict immigration and that they will have only a marginal impact on the size of migration. Note also that their scenario of no free movement is based on a restrictive assumption of zero net migration.

${ }^{6}$ Exceptions include, for example, Alvarez-Plata et al. (2003), in which the authors present several scenarios of the migration potential, depending on the date of the introduction of free movement, and Fertig (2001), in which "no free movement" and "free movement" scenarios were estimated.
} 
specific effects. In addition, in the extrapolation scenario, free movement is assumed to be introduced simultaneously for all accession countries in 2011. The results are then compared with both the existing literature and available actual evidence.

\section{A Simple Migration Scenario}

This section presents my own extrapolations of migration potential. Following other studies, the CEE countries include eight new member states ${ }^{7}$ as well as Bulgaria and Romania, partly in order to compare the results with the existing literature and partly because of the interest in the forthcoming accession of these two countries to the EU. In contrast to the existing studies, I first account for the receiving countries' fixed effects, since I believe that the unobservable pull-factors in the EU countries (such as amenities, infrastructure, culture, political situation and attitudes towards immigrants) are likely to influence the migration decisions of individuals from the CEECs. Secondly, I attempt to use both receiving and sending countries' fixed effects. Migration experience from Greece, Portugal and Spain is used to estimate the parameters of the migration function, since these countries provide a somewhat comparable situation to the recent enlargement in terms of income differentials, population sizes and transition periods regarding free movement ${ }^{8}$.

Since I have to assume for the extrapolations below that the accession countries will re-

\footnotetext{
${ }^{7}$ Czech Republic, Estonia, Hungary, Latvia, Lithuania, Poland, Slovakia, and Slovenia. Malta and Cyprus are not included because of their small size and significantly better economic situation than in the CEECs.

${ }^{8}$ GDP per capita (in PPP) in the CEECs was around $45 \%$ of the EU average before accession; in the three southern countries it was around $65 \%$ of EC average in 1981. Population sizes in both cases amounted to around $20 \%$ of EU member states.
} 
spond to the same factors in the same way in the future, choosing a more heterogeneous sample of sending countries would be problematic.

The dependent variable used is the migration rate - the ratio of the annual immigrant inflow from a sending country into the EU member state to the population of the sending country. Table 1 presents descriptive statistics. I estimate the following standard migration model:

$$
\ln M_{i j t}=\beta_{1} \ln \left(\frac{G D P_{j}}{G D P_{i}}\right)_{t}+\beta_{2} \ln \left(\frac{U_{j}}{U_{i}}\right)_{t}+\beta_{3} \ln M S_{i j t}+\beta_{4} F M_{t}+\lambda_{i j}+\theta_{t}+u_{i j t}
$$

where $M_{i j t}$ is migration rate of the source country $i$ into the destination country $j$ in year $t, G D P_{j t}$ is per capita GDP in the destination country $j$ in year $t$; $G D P_{i t}$ is per capita GDP in the source country $i$ in year $t ; U_{j t}$ is unemployment rate in the destination country $j$ in year $t ; U_{i t}$ is unemployment rate in the source country $i$ in year $t ; M S_{i j t}$ is the stock of previous migrants from country $i$ in country $j$ in the beginning of year $t ; F M_{t}$ is a free movement dummy which is equal to one after the introduction of free movement for Greece, Spain and Portugal, and is zero otherwise; $\theta_{t}$ are time fixed effects, $\lambda_{i j}$ are time-invariant country-specific effects; and $u_{i j t}$ is a disturbance term. Given the small sample size ${ }^{9}$, I use a parsimonious specification that includes only three key time-variant explanatory variables, as well as a free movement dummy. ${ }^{10}$

\footnotetext{
${ }^{9}$ While acknowledging the problem, I follow, for instance, Bauer and Zimmermann (1999) and Alecke et al. (2001), who use small samples in their analyses.

${ }^{10}$ Faini and Venturini (1994) suggest to include home country's income separately as an additional variable in order to capture non-linearities and liquidity constraints.
} 
In the first model, I control only for the receiving countries' fixed effects. In the second model, I use both receiving and sending country-specific effects. These effects capture all time-invariant factors that may affect migration between a unique pair of countries, such as distance, language similarities, common culture and history. The following twostage procedure is used. ${ }^{11}$ In the first step, I include the interactions of the sending and receiving countries (i.e., country pairs) in equation (1). ${ }^{12}$ In the second step, the estimated coefficients of these interactions are regressed on a set of time-invariant variables (or those that can be assumed not to change dramatically over time), such as geographical distance between the capitals, the Human Development Index (level of development) of the sending country, and population (labor market's absorptive capacity) of the receiving country.

Table 2 shows the estimation results. ${ }^{13}$ When only receiving country-specific effects are controlled for (column (1)), in general, all explanatory variables are significant and have the expected signs: the higher the GDP per capita in the country of destination relative to the country of origin and the larger the migrant networks, the larger is the migration flow into that country. The positive coefficient on the unemployment ratio is somewhat surprising, but it most probably reflects the liquidity constraints of individuals in the sending countries, i.e., the lower the unemployment rate in the sending countries, the more people work, and thus more can afford to migrate. When the interactions of both sending and receiving country-specific effects are used (column (2)), the signs of the

\footnotetext{
${ }^{11}$ See Fertig (2001) and Boeri et al. (2001).

${ }^{12}$ See Andrienko and Guriev (2004) for application to interregional mobility in Russia.

${ }^{13}$ For comparative purposes I have also estimated the standard gravity equation. The extrapolations based on this model were very high, since the model overestimates the parameters by omitting countryspecific variables. The results are available upon request.
} 
coefficients do not change. However, the coefficients on relative GDP and unemployment rates become insignificant, which is unsurprising given the small number of observations and collinearity with country-specific dummies. The free movement dummy is statistically insignificant in all model specifications used. ${ }^{14}$ Estimation of country-specific effects is presented in Table 3. The estimates show that the larger the distance between countries, the larger countries' fixed effects, and the bigger the population of the receiving country, the smaller is the weight of these fixed effects. The sending country's development status also influences fixed effects negatively. I was able to explain 56 percent of variation in the dependent variable and, of course, incomplete explanation of the country-specific effects reduces the forecasting power of the model. ${ }^{15}$

For the out-of-sample extrapolations, the coefficients estimated in Table 2 (Model 1 and Model 2, respectively) are combined with the data on per capita GDP, unemployment rates, and migrant stocks for the eight new EU member states as well as for Bulgaria and Romania. In order to calculate the projections, the usual assumptions were made (see Appendix). In addition, free movement of workers is assumed to be introduced in 2011 for all new member states.

Figure 1 shows simulated immigrant flows from the new member states into the EU after accession. ${ }^{16}$ Model 1 predicts the number of residents from the new member states

\footnotetext{
${ }^{14}$ I also ran three robustness checks for each of the fixed effects models. To account for economic integration and income convergence I added, first, annual GDP growth in the sending countries, then FDI inflows into the sending countries and, finally, total trade (exports plus imports) between sending countries and the EU states instead of FDI inflows. In general, coefficients on the main explanatory variables did not change much.

${ }^{15}$ In two other studies that have used a similar two-stage procedure, $\mathrm{R}^{2}$ in the second stage was 0.44 (Fertig, 2001) and 0.42 (Boeri et al., 2001), respectively.

${ }^{16}$ Note that in the extrapolations EU countries exclude Luxembourg and Ireland due to the data
} 
upon accession to amount to 254,888 persons (pessimistic GDP growth scenario) and 233,440 persons (optimistic GDP growth scenario). Model 2 yields larger results, the immigration flows being equal to 343,144 and 330,244 persons, respectively. In all specifications used, the majority of migrants is estimated to come from Romania, Poland and Bulgaria, and the main receiving countries to be Germany, Austria, Italy and the UK, which is broadly consistent with the existing studies and expectations ${ }^{17}$. Thus, the inflow of the CEECs' citizens upon accession constitutes around 0.1 per cent of the EU15 population, and the simulated immigration rates decline in the future as the convergence of incomes proceeds.

The evolution of immigrant stocks is presented in Figure 2. Model 1 implies that, depending on the GDP growth scenario, around 3.5 - 4 million CEEC citizens will reside in the EU countries within a decade after the enlargement, which constitutes 3 - 4 per cent of the CEECs' population and roughly 1 per cent of the EU15 population. Model 2 suggests a larger number - around 5 million persons, which constitutes around 5 per cent of the CEECs' population and 1.4 per cent of the EU15 population. Thus, under the assumptions mentioned above, immigration of about 3.5 - 5 million persons can be expected in the period from 2004 to 2014. In any case, this corresponds to $1-1.4$ per cent of the EU15 population.

Simultaneous legal introduction of free movement by all EU member states in 2011 would not lead to a significant increase in the number of immigrants. In all model speciscarcity.

${ }^{17}$ When estimating the model without a free movement dummy, the number increases to 0.5 million immigrants if both sending and receiving country-specific effects are included. 
fications used, the free movement dummy is statistically insignificant, and neither Figure 1 nor Figure 2 show a significant increase in immigration after 2011. The results indicate that, if income convergence occurs, emigration from the new member states will be modest, even after introduction of the free movement provision. It seems that when evaluating the expected costs and benefits of moving West, it will be worthwhile for a representative migrant to "wait and see".

Finally, Figure 3 compares these results with the existing literature, and Figure 4 with the two studies that explicitly model countries' fixed effects. These figures indicate that projections presented here seem to be consistent with both the estimates reported in the literature and the studies that explicitly model country-specific effects.

\section{Actual Developments so far}

In the absence of a perfect forecasting scenario, are the results on migration potential consistent with emerging actual evidence? While answering this question, one has to keep in mind that all the above mentioned studies estimate counterfactual scenarios, since none of them model immediate introduction of free movement by three member states and many include Bulgaria and Romania in extrapolations.

The recent EU Commission's Report presents valuable information on the migration trends in the enlarged European Union (European Commission, 2006). According to this report, there has been an increase in the overall number of permits issued for reasons of employment since the enlargement; however, this increase is rather limited (see Table 
4). On average, during May-December 2004, the number of nationals from the new member states who were granted a residence or work permit amounted to 0.3-0.4 per cent of the EU15 countries' working age population. This figure is likely to overestimate the actual number of CEEC nationals who reside in the EU15 because, first, it does not take individuals returning to their countries of origin into account, and, second, it also reflects such factors as regularization of illegal workers who had already moved into the EU several years ago. The evidence from the Eurostat Labour Force Surveys (LFS) provides a complementary picture. According to these data, in the first quarter of 2005 the proportion of the working age population from the new member states within the EU15 was 0.4 per cent on average, ranging from 0.1 per cent in France and the Netherlands to 1.4 per cent in Austria and 2 per cent in Ireland (see Table 4). These figures also indicate that the overall increase in the number of CEEC nationals in the EU15 with respect to pre-enlargement years is small and is attributable to the increase in Austria, Ireland and the UK. ${ }^{18}$

The report also suggests that there is no conclusive evidence on the direct link between the magnitude of migration flows and the transitional arrangements in place. Among the countries that have granted CEEC citizens full access to their labor markets, migration flows have increased a lot in Ireland and to a lesser extent in the UK, but have remained low in Sweden. On the contrary, the number of CEEC citizens has markedly increased in Austria, despite the presence of transition arrangements.

The data also show that a significant fraction of permits is granted to short-term

\footnotetext{
${ }^{18}$ Note that for Germany there is no data available before 2005 for comparisons.
} 
or seasonal workers. ${ }^{19} 20$ Finally, it is also worth noting that the percentage of nonEU nationals residing in the EU15 member states is significantly higher than that of CEEC nationals, and their share amounted to 5.1 per cent of the EU15 working age population in 2005 (as opposed to 0.4 per cent of the CEECs' citizens). This suggests that immigration from non-EU countries is a much more important phenomenon than the intra-EU25 migration.

The Commission's report concludes that migration flows from the new member states "are very limited and are simply not large enough to affect the EU labour market" (p.13). One has to keep in mind, however, that although in aggregate, migration flows seem not to be large, because of migration diversion, Ireland and the UK have been affected much more than was predicted.

In addition to the Commission's Report, there are two other studies of the three countries that have opened up their labor markets, which provide a complementary picture. Doyle et al. (2006) report the situation in Ireland and Sweden, and Gilpin et al. (2006) do so for the UK. According to the Doyle et al. (2006) study, the number of immigrants from the new member states in Sweden increased between 2003 and 2005 (from around 2,000 to more than 5,000). More than half of these immigrants are from Poland, followed by Lithuania and Estonia. The authors do not find a significant increase in the number

\footnotetext{
${ }^{19}$ For example, of all permits granted to the nationals from 8 new member states (excluding Cyprus and Malta) in Austria in the first half of 2005, 85 per cent were issued for less than 6 months, and in Germany 95 per cent of the work permits have been issued with time restrictions.

${ }^{20}$ Note that employment rates among immigrants from the new member states are comparable to those of the EU15 nationals, and they are generally higher than for non-EU nationals. In Ireland, Spain and the UK, CEEC immigrants have higher employment rates than natives. Moreover, the majority of CEEC citizens in the EU15 have secondary or tertiary school degree, and the percentage of those with tertiary education is higher than that of the non-EU nationals.
} 
of granted applications for social assistance. They also argue that the number of postenlargement immigrants is still small relative to Swedish population and suggest several reasons why immigration in Sweden has not increased to a larger extent. These include the few job vacancies available, low propensity to emigrate from the new member states in general and to Sweden in particular, as well as language, since many migrants may have chosen English-speaking countries.

The situation is different in Ireland. Although there is no data available from the Statistical Office that distinguishes accession state nationals from foreigners from the rest of the world before 2005, there is a remarkable increase in the number of such foreigners between 2003 and 2005, and the majority of this flow in 2005 were nationals from the new member states, amounting to roughly 26,000. The stock of citizens from eight new member states employed in Ireland in 2005 was around 62,000, according to the Quarterly National Household Survey. Personal Public Service Numbers (PPSNs) ${ }^{21}$ provide even higher figures: in 2003 there were around 11,000 PPSNs issued, in 2004 the number increased to 59,000, and in 2005 - to unprecedented 112,000. Note, however, that PPSNs are likely to overstate the stock of accession state nationals as they include those migrants who work in Ireland only for a short period and return home as well as those who were living in Ireland before enlargement. The majority of immigrants from the new member states are from Poland and the Baltic States. The authors also find no evidence of "welfare tourism" and argue that the immigration to Ireland is primarily demand-driven.

\footnotetext{
${ }^{21}$ These are individual identifiers required in order to gain employment in Ireland or to access state benefits and public services.
} 
Gilpin et al. (2006) report that in the UK the number of nationals from the new member states increased dramatically after enlargement. The authors use two data sources, the UK Labour Force Survey and Worker Registration Scheme (WRS) ${ }^{22}$. According to the former, the stock of migrants from eight accession countries (excluding Cyprus and Malta) in the UK was equal to 110,000 in 2003 , and increased to 245,000 in 2005 . According to the latter, there were 293,000 applicants to the WRS between 1 May 2004 and 30 September 2005. The vast majority of these immigrants are Polish, followed by Lithuanians and Slovaks. It should be noted that, as in the Irish case, the WRS figures are likely to overstate the stock of migrants, since they include those who work in the UK only temporarily and those who were living in the UK before enlargement. Again, the number of accession countries nationals applying to social benefits in the UK is very low.

Overall, recent evidence seems to indicate that immigration from the new member states to the EU15 as a whole has increased since enlargement, but the aggregate increase is not large. When looking at the three countries that have opened up their labor markets, however, the picture is more complicated, as the data indicates a large increase in the number of immigrants from the new member states in Ireland and the UK. One has to keep in mind, however, different data limitations, such as the inability to account for temporary migrants and the fact that many of these individuals may have already been living in these countries before the accession.

\footnotetext{
${ }^{22}$ The workers from the new member states are obliged to register on the Home Office administered WRS if they employed in the UK for a month or more.
} 


\section{Conclusions}

This paper reviews the existing literature on the migration potential in the enlarged Europe and suggests one more migration scenario that, contrary to the existing literature, accounts for both sending and receiving countries' unobserved heterogeneity and estimates a counterfactual scenario in which all EU incumbents introduce free movement of workers simultaneously in 2011. The findings are then reconciled with the recent actual evidence.

In line with the existing literature, the suggested migration scenario shows that future immigration flows will decline as the convergence of incomes proceeds, and the cumulative stock of migrants is expected to reach 1 per cent of the EU15 population in the decade following accession. These results are consistent with the estimates reported in the literature. In all model specifications used, the majority of migrants is predicted to come from Romania, Poland and Bulgaria, and the main receiving countries to be Germany and Austria. In addition, the legal introduction of the free movement provision in 2011 is not expected to increase immigration significantly. This counterfactual scenario suggests that if free movement had been postponed by all old EU member states, immigration would not have increased significantly upon the legal introduction of free movement. By that time migrant stocks in the EU might already be close to their equilibrium levels, or it might be worthwhile for a representative migrant to stay in the East and to "wait and see". It should be kept in mind, however, that such "guesstimates" are always subject to many assumptions and the results have to be interpreted with caution.

Overall, the results of the majority of the existing studies, including the ones presented 
here, confirm the experience of previous European integration. The emerging actual evidence also seems to support these conclusions on aggregate, however because of migration diversion Ireland and the UK have been affected much more than was predicted. 


\section{References}

[1] Alecke, Bjorn, Huber, Peter and Untiedt, Gerhard (2001). What a Difference a Constant Makes: How Predictable are International Migration Flows? In: OECD (ed.), Migration Policies and EU Enlargement - The Case of Central and Eastern Europe, pp. 63-78, OECD, Paris.

[2] Alvarez-Plata, Patricia, Brücker, Herbert and Siliverstovs, Boris (2003). Potential Migration from Central and Eastern Europe into the EU-15 - An Update. Report for the European Commission, DG Employment and Social Affairs, Berlin: German Institute for Economic Research (DIW Berlin).

[3] Andrienko, Juri and Guriev, Sergei M. (2004). Determinants of Interregional Mobility in Russia. Economics of Transition 12 (1): 1-27.

[4] Bali Online: www.indo.com/distance/index.html

[5] Bauer, Thomas K. and Zimmermann, Klaus F. (1999). Assessment of Possible Migration Pressure and its Labour Market Impact Following EU Enlargement to Central and Eastern Europe. IZA Research Report No.3. Bonn: Institute for the Study of Labor (IZA).

[6] Boeri, Tito and Brücker, Herbert (2005). Why Are Europeans So Tough on Migrants? Economic Policy 20 (44): 629-703.

[7] Boeri, Tito et al. (2001). The Impact of Eastern Enlargement on Employment and Labour Markets in the EU Member States. Report for the European Commission, DG Employment and Social Affairs. European Integration Consortium: DIW, CEPR, FIEF, IAS, IGIER. Berlin and Milan.

[8] Brücker, Herbert (2001). Die Folgen der Freizügigkeit für die Ost-West-Migration. Schlussfolgerungen aus einer Zeitreihenanalyse der Migration nach Deutschland, 1967-1998. Konjunkturpolitik 52 (Supplement): 17-54.

[9] Brücker, Herbert, and Siliverstovs, Boris (2006). On the Estimation and Forecasting of International Migration: How Relevant is Heterogeneity Across Countries? Empirical Economics 31(3): 735-54.

[10] Burda, Michael C. (1995). Migration and the Option Value of Waiting. Economic and Social Review 27: 1-19.

[11] Chamberlain, Gary (1985). Panel Data. In: Griliches, Zvi and Intriligator, Michael D. (eds.) Handbook of Economterics, Volume II, Amsterdam: North-Holland. 
[12] Doyle, Nicola, Gerard Hughes and Eskil Wadensjö (2006). Freedom of Movement for Workers from Central and Eastern Europe. Experiences in Ireland and Sweden. Swedish Institute for European Policy Studies. Report No. 5, May/2006. Stockholm, Sweden.

[13] Dustmann, Christian et al. (2003). The Impact of EU Enlargement on Migration Flows. UK Home Office Report, 2003.

[14] EBRD (2003). Transition Report. Integration and Regional Cooperation.

[15] European Commission (2006). Report on the Functioning of the Transitional Arrangements set out in the 2003 Accession Treaty (period 1 May 2004-30 April 2006). Communication from the Commission, COM(2006) 48 final.

[16] Eurostat (2000). Patterns and Trends in International Migration in Western Europe. European Communities, Luxembourg, Ch. 9: The Migration Impacts of Previous EU Enlargements And Lessons for the Future: 174-82.

[17] Eurostat Statistical Yearbook, various issues.

[18] Faini, Ricardo and Venturini, Alessandra (1994). Migration and Growth: The Experience of Southern Europe. CEPR Discussion Paper No. 964.

[19] Fassmann, Heinz, and Hintermann, Christiane (1997). Migrationspotential Ostmitteleuropa, ISR Forschungsberichte 15, Institut für Stadt- und Regionalforschung, Vienna.

[20] Fertig, Michael (2001). The Economic Impact of EU Enlargement: Assessing the Migration Potential. Empirical Economics 26 (4): 707-20

[21] Fertig, Michael and Schmidt, Christoph M. (2001). Aggregate-Level Migration Studies As a Tool for Forecasting Future Migration Streams. In: Djajic, Slobodan (ed.), International Migration: Trends, Policy and Economic Impact, pp. 110-36. London/New York.

[22] Flaig, Gebhard (2001). Die Abschätzung der Migrationspotentiale der Osteuropäischen EU-Beitrittsländer. Konjunkturpolitik 52 (Supplement): 55-76.

[23] Franzmeyer, Fritz and Brücker, Herbert (1997). Europäische Union, Osterweiterung und Arbeitskräftemigration. DIW-Wochenbericht 64 (5): 89-96.

[24] Ghatak, Subrata, Levine, Paul and Price, Stephen W. (1996). Migration Theories and Evidence: An Assessment. Journal of Economics Surveys 10 (2): 159-98.

[25] Gilpin, Nicola, Matthew Henty, Sara Lemos, Jonathan Portes and Chris Bullen (2006). The Impact of Free Movement of Workers from Central and Eastern Europe on the UK Labour Market. Working Paper No. 29, Department of Work and Pensions, UK. 
[26] Harris, John R. and Todaro, Michael P. (1970). Migration, Unemployment and Development: A Two-Sector Analysis. American Economic Review 60: 126-42.

[27] Hatton, Timothy J. (1995). A Model of UK Emigration, 1870-1913. Review of Economics and Statistics 77 (3): 407-15.

[28] Hille, Hubertus and Straubhaar, Thomas (2001). The Impact of the EU Enlargement on Migration Movements and Economic Integration: Results of Recent Studies. In: OECD (ed.), Migration Policies and EU Enlargement - The Case of Central and Eastern Europe, pp. 79-100. OECD, Paris.

[29] Kraus, Margit and Schwager, Robert (2000). EU Enlargement and Immigration. ZEW Discussion Paper No. 00-09. Zentrum fur Europaische Wirtschaftsforschung (ZEW), Manheim.

[30] Layard, Richard et al. (1992). East-West Migration: The Alternatives. Cambridge MA: MIT-Press.

[31] Lundborg, Per (1998). The Free Movement of Labour between Sweden and the New EU Members. In: Committee on the Economic Effects of EU Enlargement (eds.), $A$ Bigger and Better Europe? - Final Report, Government Official Reports, Stockholm.

[32] Massey, Douglas S. et al. (1993). Theories of International Migration: A Review and Appraisal. Population and Development Review 19 (3): 431-66.

[33] Orlowski, Witold M., Leszek Zienkowski, and Leon Podkaminer (2000). Potential Migration Flows from Central and Eastern Europe to Austria After the Enlargement. WIIW Project Nr. 7919, Vienna, Austria.

[34] Sinn, Hans-Werner et al (2000). EU-Erweiterung und Arbeitskräftemigration Wege zu einer schrittweisen Annäherung der Arbeitsmärkte. Studie im Auftrag des Bundesministeriums fur Arbeit und Sozialordnung. Ifo Institut, München.

[35] Sjaastad, Larry A. (1962). The Costs and Returns of Human Migration. Journal of Political Economy 70 (5), Part 2: 80-93.

[36] Stark, Oded (1984). Migration Decision Making: A Review Essay. Journal of Development Economics 14: 251-59.

[37] Straubhaar, Thomas (2001). East-West Migration: Will It Be a Problem? Intereconomics, July/August 2001.

[38] Todaro, Michael P. (1969). A Model of Labor Migration and Urban Unemployment in Less Developed Countries. American Economic Review, 69: 486-99.

[39] United Nations (2002). Human Development Report. 
[40] Wallace, Claire (1998). Migration Potential in Central and Eastern Europe. International Organization for Migration (IOM), Geneva.

[41] World Bank (2002). World Development Indicators, CD-Rom, Washington. 
Table 1: Summary statistics

\begin{tabular}{lcc}
\hline \hline \multicolumn{1}{c}{ Variable } & Mean & Std. dev. \\
\hline log GDP ratio & 0.3 & 0.2 \\
log unemployment ratio & -0.2 & 0.8 \\
log stock of migrants & 8.1 & 2.4 \\
free movement & 0.6 & 0.5 \\
distance & 2099 & 696 \\
HDI & 0.85 & 0.03 \\
population, receiving & 24740 & 26486 \\
Notes: sending countries include Spain, Portugal and Greece, receiving countries are EU member states. Years: $1986-$ \\
Final number of observations is 169. GDP ratio is the ratio of GDPs per capita of the respective receiving country \\
hending country, unemployment ratio is the ratio of unemployment rate of the respective receiving country to the \\
ling country, free movement is a dummy that equals one after the legal introduction of the free movement provision for \\
ece, Spain and Portugal, distance is the geographical distance in kms. between the capitals of sending and receiving \\
tries, HDI stands for Human Development Index, population, receiving is population size in thousands.
\end{tabular}

Table 2: Estimation of the migration function

\begin{tabular}{|c|c|c|}
\hline & $\begin{array}{c}\text { Receiving } \\
\text { countries' FE } \\
(1)\end{array}$ & $\begin{array}{c}\text { Countries } \\
\text { pairs' FE } \\
(2)\end{array}$ \\
\hline $\log$ GDP ratio & $2.55(3.53)$ & $1.11(0.85)$ \\
\hline log unemployment ratio & $0.81(4.76)$ & $0.04(0.15)$ \\
\hline log stock of migrants & $0.78(9.85)$ & $2.3(5.09)$ \\
\hline free movement & $0.07(0.45)$ & $-0.16(0.93)$ \\
\hline $\mathrm{R}^{2}$ & 0.87 & 0.98 \\
\hline
\end{tabular}

Table 3: Explanation of the country-specific effects

\begin{tabular}{lcc}
\hline \hline & Coefficient & t-value \\
\cline { 2 - 3 } distance & 0.002 & 9.09 \\
HDI, sending & -24.15 & 4.42 \\
population, receiving & -0.0001 & 14.61 \\
$\mathrm{R}^{2}$ & & 0.56
\end{tabular}

Notes: dependent variable is country-pairs' fixed effects retrieved from the first step regression of migration rate on GDP ratio, unemployment ratio, stock of migrants and both sending and receiving countries' fixed effects. t-values are heteroscedasticity corrected. Number of observations is 246 . See text for definitions and data sources. 
Table 4: Nationals from the new member states, as percentage of the destination country's working age population (aged 15-64)

\begin{tabular}{lcccc}
\hline \hline Country of & Administrative data & \multicolumn{3}{c}{ Labour Force Survey $^{2}$} \\
\cline { 2 - 5 } destination & 2004 & 2003 & 2004 & 2005 \\
\hline Belgium & 0.2 & 0.2 & 0.2 & 0.2 \\
Denmark & 0.1 & n.a. & n.a. & n.a. \\
Germany & $0.2 / 0.9$ & n.a. & n.a. & 0.7 \\
Greece & 0.1 & 0.3 & 0.4 & 0.4 \\
Spain & 0.0 & 0.2 & 0.2 & 0.2 \\
France & 0.0 & 0.1 & 0.1 & 0.1 \\
Ireland & 1.9 & n.a. & n.a. & 2.0 \\
Italy & 0.1 & n.a. & n.a. & n.a. \\
Luxembourg & n.a. & 0.3 & 0.3 & 0.3 \\
Netherlands & 0.2 & 0.1 & 0.1 & 0.1 \\
Austria & $0.7 / 1.2$ & 0.7 & 0.8 & 1.4 \\
Portugal & 0.0 & n.a. & n.a. & n.a. \\
Finland & 0.0 & 0.3 & 0.3 & 0.3 \\
Sweden & 0.1 & 0.2 & 0.2 & 0.2 \\
UK & 0.4 & 0.2 & 0.3 & 0.4 \\
\hline EU15 & $0.3 / 0.4$ & 0.2 & 0.2 & 0.4
\end{tabular}

Source: Tables on pp. 8 and 9, European Commission (2006) and author's modifications.

Notes: n.a. stands for not available. 1) Administrative data refer to the number of applications/work or residence permits issued (flows), except for Germany, where the first figure refers to the stock of workers, and for Austria, where the first figure refers to the average annual stock of employees. Figures on residence permits refer to permits issued for employment reasons only, except for Belgium. The figure for Ireland refers to Personal Public Service Numbers issued not only for employment reasons, but also for other purposes, including welfare, health and other public services. Figures for France, Italy, Austria and Germany are for 8 new member states, excluding Cyprus and Malta. 2) Eurostat, Labour Force Survey Q1, Ireland 2005 Q2. EU15 aggregate without Germany and Ireland in 2003-2004, and without Italy in 2003-2005. 


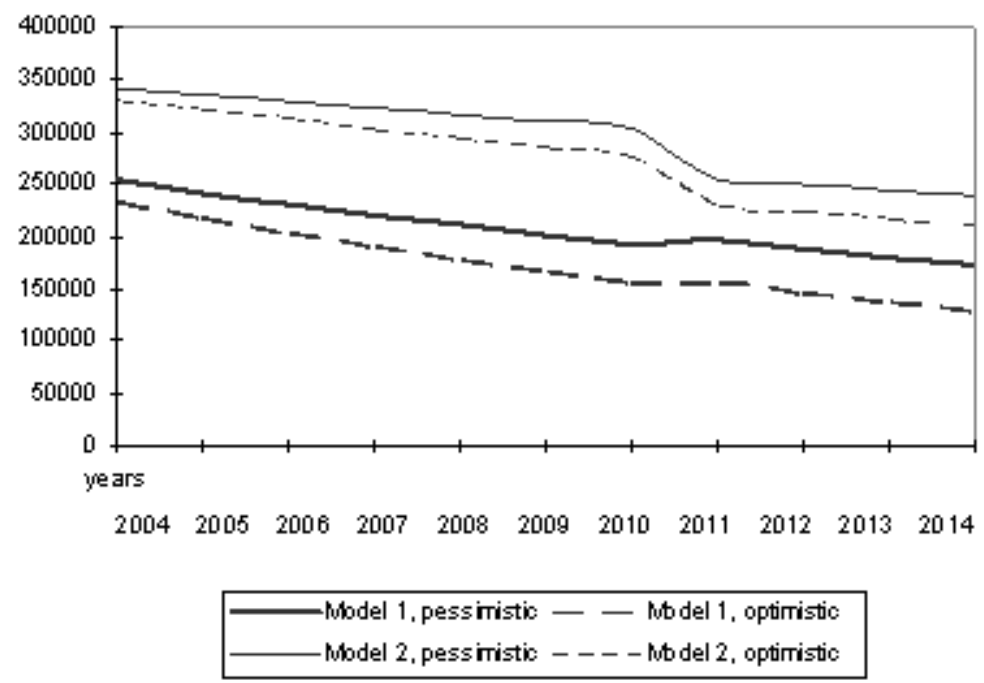

Figure 1: Projected annual inflows of residents from the CEECs into the EU. Note: EU countries exclude Luxembourg and Ireland due to data scarcity.

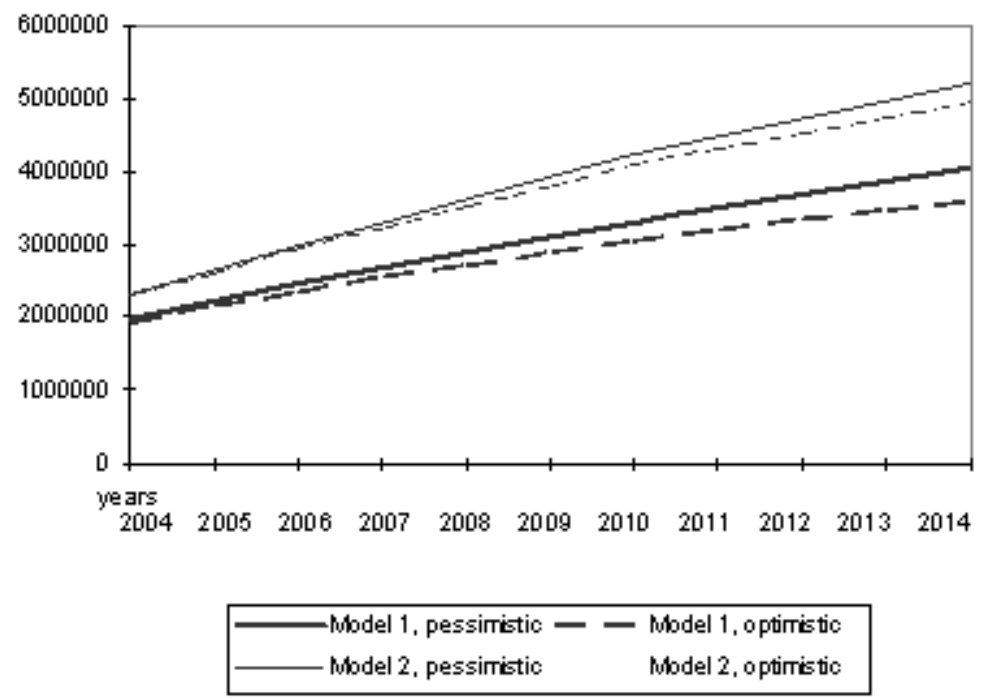

Figure 2: Evolution of the stock of residents from the CEECs residing in the EU. Note: EU countries exclude Luxembourg and Ireland due to data scarcity. 


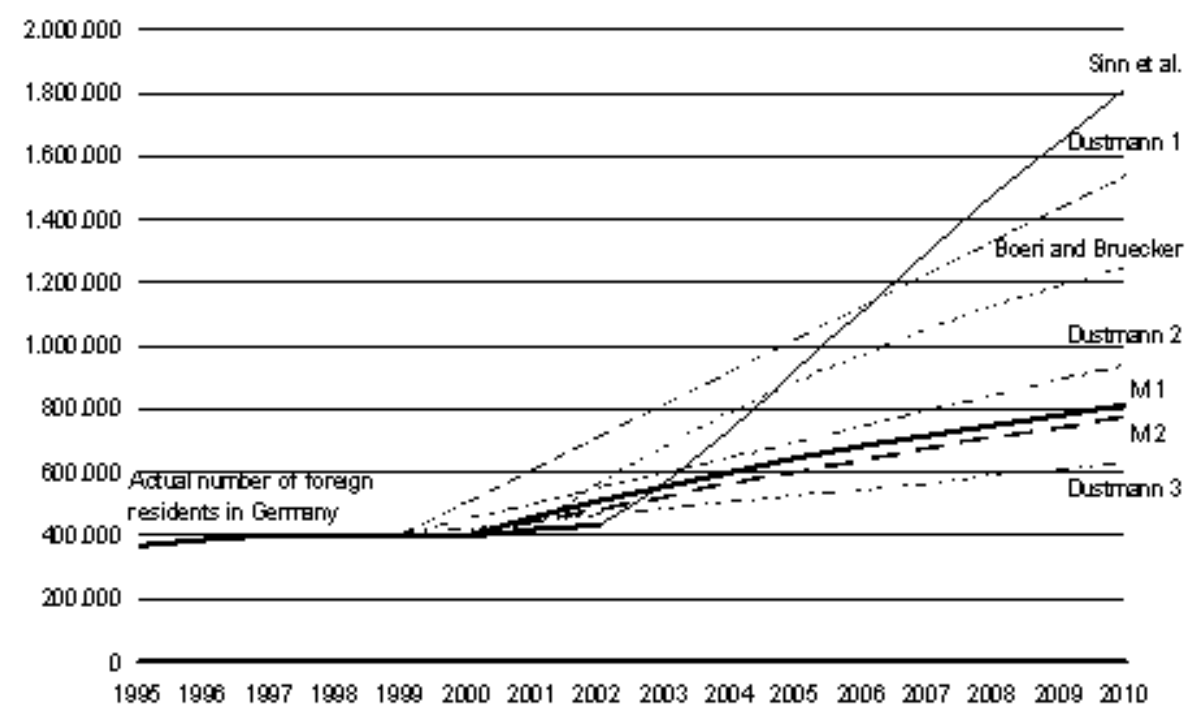

Figure 3: Comparison with other studies: Stock of the CEEC residents in Germany. Source: EBRD (2003) and author's modifications. Notes: CEEC include eight new member states without Cyprus and Malta. M1 refers to Model 1, M2 - to Model 2, and the results for the pessimistic GDP growth scenario are presented (Bulgaria and Romania are excluded). Dustmann 1, 2, 3 - stand for Economic 04, Economic 01 and Baseline 01 scenarios in Dustmann et al. (2003), and figures include Cyprus and Malta. Boeri and Bruecker stands for Boeri et al. (2001) estimates, excluding Bulgaria and Romania. Sinn et al. stands for Sinn et al. (2000) and the CEECs include 4 countries: Czech Republic, Hungary, Poland and Slovakia. 


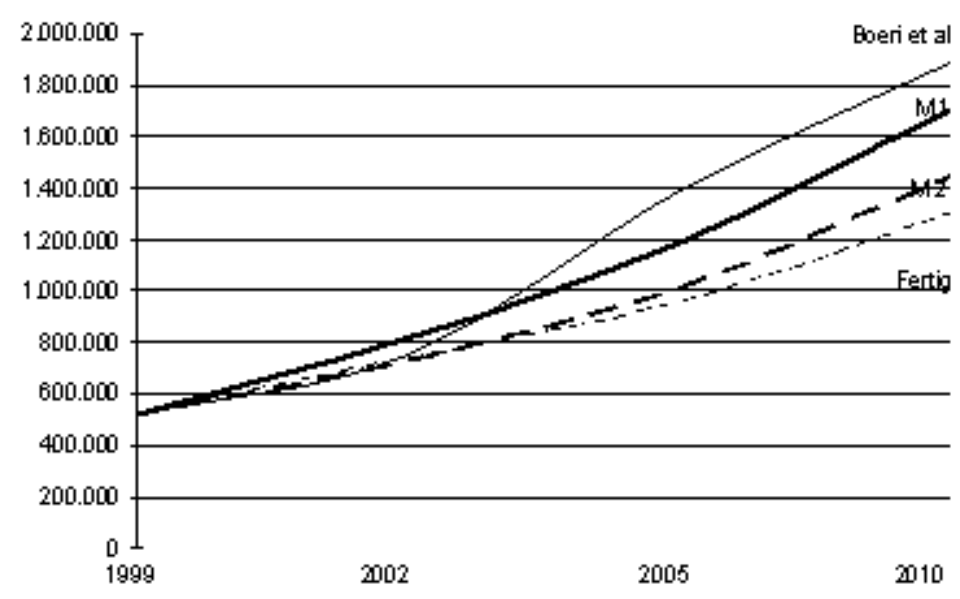

Figure 4: Comparison with the studies that estimate fixed effects: Stock of the CEEC residents in Germany. Source: author's calculations. Notes: CEEC include eight accession countries (without Cyprus and Malta), plus Bulgaria and Romania. M1 refers to Model 1, M2 - to Model 2, and the results for the pessimistic GDP growth scenario are presented. Boeri et al. refers for Boeri et al. (2001) estimates for Germany under the baseline scenario; Fertig stands for Fertig's (2001) estimates for Germany under the medium convergence scenario.

\section{Data Appendix}

The data used for estimation cover annual migration from Greece, Portugal and Spain into the EU countries during 1985-1997, as well as GDPs per capita in PPP, unemployment rates (as defined by the ILO), and population sizes of the southern countries and of all EU member states. This is the same dataset as in Bauer and Zimmermann (1999). These data were augmented with the following variables: geographical distance (between two countries' capitals ${ }^{23}$ ) from the Bali Online distance calculator, Human Development Index from the United Nations (2002), annual percentage GDP growth, net inflows of the foreign direct investment (FDI), total trade with the EU (exports plus imports) in current prices from the IMF Direction of Trade Statistics database and Eurostat Yearbooks (various issues). For the extrapolations, GDPs per capita in PPP, unemployment rates and population sizes of the CEECs as well as the EU in the year 2000 were taken from Eurostat Yearbook (2002) and World Bank's World Development Indicators database. The stock of migrants from the CEECs is extracted from the Eurostat's New Cronos database. Data for the stock of immigrants from CEECs in Greece are of 1998, France 1999, Austria - 1999.

For the extrapolations, the following assumptions were made based on the existing

\footnotetext{
${ }^{23}$ Except for Slovakia-Austria, where distance between Bratislava-Salzburg was calculated, and EstoniaFinland, where distance between Tallinn-Turku was calculated (since the distance between the capitals in these cases is too small to be representative).
} 
literature:

1) annual GDP growth for the CEECs was taken from Orlowski et al. (2000) where it was calculated according to endogenous growth theory for two scenarios: low growth (pessimistic) and high growth (optimistic). Using these growth rates, the GDPs per capita were calculated for ten CEECs until 2015;

2) GDP in the EU15 is assumed to grow at 2 percent rate;

3) population in both regions is assumed to remain unchanged;

4) year 2000 unemployment rates for both regions are assumed to remain unchanged;

$5)$ the stock of migrants is assumed to stay constant due to two-way migration;

6) Bulgaria and Romania are included into the projections as if they had already joined the EU in 2004, in order to compare the results with the existing studies. 